\title{
WAKAF BENDA BERGERAK DALAM PERSPEKTIF HUKUM ISLAM DAN PERUNDANG-UNDANGAN DI INDONESIA
}

\author{
Yusep Rafiqi \\ Dosen Fakultas Agama Islam Universitas Siliwangi Tasikmalaya \\ yusefrafiqi@gmail.com \\ Received: 04-10-2018, Accepted: 15-10-2018, Published: 26-10-2018
}

\begin{abstract}
In Islamic jurisprudence, the object that is endowed (al-mawqûf) is divided into two: the moveable and the immoveable waqf. The problematic object of the waqf affects the legitimacy of waqf action over the two categories of waqf objects. Meanwhile, in Act No. 41 of 2004 on Waqf of the Sixth Division of Waqf Property, Article 16, paragraph (3) stated that moveable objects that can be endowed are inaccessible goods because they are consumed. The tradition of donating moveable objects in Indonesia has not been popular compared with immovable objects in the form of land and buildings. This has implications for the productivity of waqf assets and the preservation of their benefits. Thus, the existence of waqf has not made wider social contribution because it is only for consumptive interest only. This paper is structured to analyze the extent to which the endowments of moveable objects in Islamic jurisprudence are absorbed into Indonesian legislation.
\end{abstract}

Keywords: endowment of moveable objects, cash waqf, legislation

\begin{abstract}
Abstrak
Di dalam hukum Islam, benda yang diwakafkan (al-mawquf) terbagi menjadi dua: benda wakaf bergerak dan tidak bergerak. Problematika obyek wakaf tersebut mempengaruhi pada keabsahan tindakan wakaf atas dua kategorisasi benda wakaf tersebut. Sementara itu, dalam UndangUndang Nomor 41 tahun 2004 tentang Wakaf Bagian Keenam Harta Benda Wakaf, Pasal 16, ayat (3) dinyatakan bahwa benda bergerak yang bisa diwakafkan adalah harta benda yang tidak bisa habis karena dikonsumsi. Adapun tradisi mewakafkan benda bergerak di Indonesia belum populer dibandingkan dengan wakaf benda tidak bergerak yang berupa tanah dan bangunan. Hal ini berimplikasi pada produktifitas aset wakaf dan pengabadian kemanfaatannya. Dengan demikian, keberadaan
\end{abstract}


wakaf belum memberikan kontribusi sosial yang lebih luas karena hanya untuk kepentingan yang bersifat konsumtif semata. Makalah ini disusun untuk menganalisis sejauh mana wakaf benda bergerak dalam hukum Islam diserap ke dalam perundang-undangan di Indonesia.

Kata Kunci: wakaf benda bergerak, wakaf uang, perundang-undangan

\section{A. Pendahuluan}

Di Indonesia, pengelolaan harta wakaf belum begitu berkembang dibandingkan dengan negara lain. Walaupun sumbangsih tanah wakaf begitu besar data Departemen Agama menyebut jumlah tanah wakaf di Indonesia sebanyak 430.766 lokasi dengan luas mencapai 1.615.791.832, $27 \mathrm{~m}^{2}$ yang tersebar di 366.595 lokasi $^{1}$ namun, sangat sedikit yang produktif. Hal ini diperkuat dengan hasil penelitian Pusat Bahasa dan Budaya (PBB) UIN Syarif Hidayatullah Jakarta (CSRC UIN: 2006) menunjukkan, bahwa harta wakaf lebih banyak bersifat diam (77\%) daripada yang menghasilkan atau produktif (23\%). Temuan lain menunjukkan, pemanfaatan terbesar harta wakaf adalah masjid (79\%) daripada

1 Direktorat Pemberdayaan Wakaf. (2008). Data Luas dan Lokasi Tanah Wakaf Nasional Sampai Dengan Tahun. Jakarta, 22 April 2008. peruntukkan lainnya, dan lebih banyak berada di wilayah pedesaan $(59 \%)$ daripada perkotaan $(41 \%)^{2}$. Dilihat dari sudut pandang produktifitas, manajemen wakaf di Indonesia masih jauh tertinggal dibandingkan dengan Mesir, Arab Saudi, Kuwait dan Turki.

Dalam kasus di Indonesia, perkembangan pengelolaan harta wakaf secara profesional masih terhitung lambat. Hal ini bisa ditelusuri dari periodisasi perkembangan wakaf di Indonesia yang terbagi menjadi tiga peride. Pertama, periode tradisional. Periode ini ditandai dengan banyaknya harta wakaf tidak bergerak yang diperuntukkan (mauquf 'alayh) bagi mesjid, madrasah, kuburan dan yayasan-yayasan sosial. Sehingga keberadaan wakaf belum memberikan kontribusi sosial yang lebih luas karena hanya untuk kepentingan yang

${ }^{2}$ Rahmat Dahlan. (2014). "Faktor-Faktor Yang Mempengaruhi Persepsi Nazhir Terhadap Wakaf Uang. Jurnal al-Iqtishad . VI, (02). hlm. 306. 
bersifat konsumtif semata. Periode stagnan ini diakibatkan oleh kebekuan pemahaman terhadap hal-ihwal wakaf, Nazhir wakaf yang masih bersifat tradisional dan peraturan perundangan yang belum memadai. Kedua, periode semi profesional. Dalam catatan Departemen Agama, periode ini tidak jauh berbeda dengan periode yang pertama, hanya saja beberapa mesjid wakaf, terutama yang berlokasi strategis, sudah dikembangkan sedemikian rupa dengan penambahan gedung aula, balai pertemuan, perpustakaan, lembaga-lembaga pendidikan. Untuk wakaf tanah pertanian, sudah dikembangkan dengan didirikannya unit-unit usaha seperti penggilingan padi, toko-toko ritel dan sebagainya. Ketiga, periode profesional. Periode ini ditandai dengan dimulainya manajemen nazhir secara profesional yang berdampak positif pada gerakan wakaf yang masif. Pada periode ini ditandai pula dengan lahirnya Undangundang No. 41 Tahun 2004 tentang Wakaf. Kemudian muncul pula gagasan wakaf investasi, yang di Indonesia sudah dimulai oleh Dompet
Dhuafa Republika bekerja sama dengan Batasa (BTS) Capital ${ }^{3}$.

Sementara itu, di tengah krisis sosial ekonomi yang melanda hampir seluruh masyarakat muslim di Indonesia dewasa ini, terobosan baru dalam paradigma ekonomi umat menjadi suatu yang mendesak untuk digagas. Dr. Khurshid Ahmad dalam pengantar bagi karya Dr. Muhammad Umer Chapra, Islam and The Economic Challenge, menyatakan bahwa The economic crisis of our times remains as deep and distressing as ever and can be ignored only at the gravest peril. There is an urgent need for objective analysis of the entire economic landscape with a view to finding a fresh approach which seeks the objectives of efficiency and equity simutaneously and for all human being. ${ }^{4}$ Ekonom asal Pakistan ini menekankan pentingnya analisis yang obyektif tentang lanskap ekonomi terkini yang berpijak dari prinsip efisiensi dan berkeadilan bagi seluruh manusia.

\footnotetext{
3 Direktorat Pemberdayaan Wakaf. Kementerian Agama Republik Indonesia, Strategi Pengembangan Wakaf Tunai di Indonesia, tahun 2013, hlm. 1-4.

4 M. Umer Chapra. (11532, 1992/1413 $\mathrm{H})$. Islam and the Economic Challenge, The Islamic Foundation And The International Institute of Islamic Thought. Riyadh. hlm. 12.
} 
Dalam pandangan Muhammad Nejatullah al-Shiddiqi sebagaimana dikutip oleh Suhrawardi K Lubis menyatakan bahwa aktifitas ekonomi dalam pandangan Islam bertujuan untuk: 1) memenuhi kebutuhan hidup seseorang secara sederhana, 2) memenuhi kebutuhan keluarga, 3) memenuhi kebutuhan jangka panjang, 4) menyediakan kebutuhan keluarga yang ditinggalkan, 5) memberikan bantuan sosial dan sumbangan menurut jalan Allah ${ }^{5}$. Ekonomi Islam, sesuai dengan doktrin $\mathrm{Habl}$ min Allah dan Habl min al-nâs ${ }^{6}$, pada akhirnya menjadi suatu sistem ekonomi yang rahmatan li al-'alamin. Hal ini bisa dilihat dari banyaknya lembagalembaga keuangan publik yang menerapkan prinsip syariah. Bahkan di beberapa negara yang berhaluan hukum sekular, sistem ekonomi syariah sudah diperkenalkan dan dipraktikkan pada lembaga-lembaga keuangan mereka. M. Umer Chapra ${ }^{7}$ menyatakan bahwa Islam

5 Suhrawardi K Lubis. (2004). Hukum Ekonomi Islam. (Jakarta: Sinar Grafika, Jakarta. III (02)

${ }^{6}$ Q.S. Ali-Imran (3): 112.

7 M. Umer Chapra. (2012). Alquran Menuju Sistem Moneter yang Adil. diterjemahkan oleh Lukman Hakim, Yogyakarta: Dana Bhakti Prima Yasa, 1997, Xxxiii, dalam Yadi Janwari, Tantangan dan telah menawarkan sebuah sistem ekonomi. Islam menekankan agar menggunakan sumber daya yang diberikan Allah untuk memenuhi kebutuhan-kebutuhan mendasar manusia dan menyediakan mereka kondisi kehidupan yang laik.

\section{B. WAKAF BENDA BERGERAK DALAM PERSPEKTIF \\ HUKUM ISLAM}

Fikih wakaf mengenal adanya dua bentuk wakaf apabila dilihat dari konteks kemungkinan pemindahannya ${ }^{8}$; yaitu: wakaf benda tidak bergerak (waqf al-iqâr) dan wakaf benda bergerak (waqf al-manqûl). Benda tidak bergerak (al-'iqâr) adalah benda yang tidak bisa dipindahkan dari tempatnya semula, seperti rumah dan tanah atau sesuatu yang tetap. Sementara, yang disebut dengan benda bergerak (al-manqûl) adalah benda yang bisa dipindahkan dari tempatnya semula, atau sesuatu yang bisa dipindahkan dari satu tempat ke tempat lainnya seperti mata uang,

Inisiasi Dalam Implementasi Ekonomi Syariah di Indonesia. Jurnal Ahkam. Vol. XII, (02), hlm. 89.

8 Lihat, Abu 'Amr Dubyan Ibn Muhammad al-Dubyan. (1432 H). alMu'amalat al-Maliyah Ashalah wa Mu'asharah. Riyadh: Maktabah al-Malik Fahd al-Wathaniyyah. hlm. 165. 
binatang, timbangan dan sebagainya. Selanjutnya, para ulama berbeda pendapat dalam hal kategorisasi kedua bentuk harta tersebut; apakah benda yang berubah bentuknya ketika dipindahkan itu disebut benda tidak bergerak atau benda bergerak seperti bangunan dan pepohonan. Dalam hal ini, ada dua pendapat yang berbeda:

1. Pendapat ulama Hanafiyah yang menyatakan bahwa benda tersebut termasuk ke dalam benda bergerak (al-manqûl) kecuali apabila bangunan dan pepohonan tersebut tetap di atas tanah.

2. Pendapat Jumhur Ulama selain Hanafiyah menyatakan bahwa benda tersebut masuk dalam kategori benda tidak bergerak $(\text { al- 'iqâr })^{9}$.

Dari beberapa perbedaan pendapat para ulama atas definisi dan kategorisasi benda tidak bergerak (al'iqâr) dan benda bergerak (al-manqûl) ini, mempengaruhi pula pada keabsahan tindakan wakaf atas dua kategorisasi benda wakaf tersebut. Keabsahan mewakafkan harta tidak bergerak menjadi dalil atas keabsahan mewakafkan harta

\footnotetext{
${ }^{9}$ Abu 'Amr Dubyan Ibn Muhammad alDubyan. 1432 H). al-Mu'amalat al-Maliyah Ashalah wa Mu'asharah. hlm. 166.
}

bergerak selama memegang prinsip menahan pokok dan menyalurkan manfaatnya (tahbîs al-ashl wa tasbîl almanfaah). Imam al-Mawardi berkata bahwa wakaf benda tidak bergerak adalah sah dengan tanpa perdebatan sebagaimana mereka juga sepakat (ijma') atas keabsahan mewakafkan benda bergerak yang mengikuti keabsahan wakaf benda tidak bergerak. Imam alZayla'iy berkata bahwa wakaf benda bergerak mengikuti wakaf benda tidak bergerak adalah diperbolehkan berdasarkan kesepakatan para ulama $(\text { ijma })^{10}$.

Adapun beberapa pernyataan para ulama atas keabsahan wakaf benda tidak bergerak dan benda bergerak adalah sebagai berikut:

a) Imam Abu Hanifah dan berdasarkan periwayatan Imam Ahmad menyatakan bahwa wakaf benda bergerak adalah tidak sah.

b) Mazhab Maliki, Syafi'i dan yang masyhur di kalangan ulama mazhab Hanbali menyatakan bahwa tidak ada perbedaan antara benda tidak bergerak dan

${ }^{10} \mathrm{Abu}$ 'Amr Dubyan Ibn Muhammad alDubyan. (1432 H). al-Mu'amalat al-Maliyah Ashalah wa Mu'asharah. hlm. 166. 
benda bergerak di dalam wakaf. Semuanya menyatakan sah dalam wakaf.

c) Pendapat Abu Yusuf dari Mazhab Hanafiy menyatakan bahwa yang termasuk kategori benda bergerak yang sah dalam wakaf hanya mencakup persenjataan dan hewan (kuda dan keledai).

d) Sementara itu, pendapat Muhammad Ibn al-Hasan alSyaybani dari Mazhab Hanafy menyatakan sah wakaf benda bergerak berdasarkan adat kebiasaan wakaf di suatu tempat. Musthafa Ahmad al-Zarqa menyatakan bahwa wakaf benda bergerak terbagi atas dua kategori ${ }^{11}$ :

1. Benda bergerak yang diwakafkan mengikuti benda tidak bergerak, yang meliputi: wakaf suatu kawasan yang di dalamnya terdiri dari peralatan pertanian, hewan-hewan dan bangunan, atau wakaf bangunan yang di dalamnya terdiri dari beragam peralatan, atau wakaf tanah yang di atasnya terdiri dari

${ }^{11}$ Lihat, Al-Syaikh Musthafa Ahmad alZarqa. (1419 H/1998 M). Ahkam al-Awqaf. Amman: Dar Ammar, hlm. 59. beragam tanam-tanaman. Jenis wakaf seperti ini sah dilihat dari sudut pandang wakaf benda tidak bergerak dan bergerak sekaligus. Demikian pula wakaf yang berupa persenjataan dan baju besi, maka wakaf benda bergerak seperti ini sah berdasarkan sunnah.

2. Benda bergerak yang diwakafkan secara mandiri. Wakaf benda bergerak dalam kategori ini dimaksudkan sebagai benda yang bisa dimanfaatkan secara mandiri pula seperti buku-buku dan mushhaf, peralatan untuk memandikan jenazah, ambulance, atau apa saja yang bisa digunakan dalam rangka pengembangan ilmu pengetahuan.

Dalam hal wakaf benda bergerak secara mandiri, al-Zarqa mendasarinya pada dua kategori pula:

1. Berupa harta yang populer secara tradisi (al-urf) masyarakat setempat. Wakaf dalam kategori ini adalah wakaf yang tidak berbenturan dengan nash. Di sisi lain, kaidah fiqhiyyah yang 
mendukung diberlakukannya hukum wakaf benda bergerak dalam kategori tradisi masyarakat setempat adalah alâdah al-muhakkamah.

2. Berupa harta yang tidak populer di kalangan maasyarakat setempat. Wakaf benda bergerak yang masuk dalam kategori ini adalah seperti perkakas rumah, binatang. Wakaf seperti ini tidak sah karena pada dasarnya, wakaf haruslah berupa benda bergerak yang tetap dan bertahan lama.

Al-kabisi, seraya menyitir pendapat dari ulama Hanafiyah, wakaf benda bergerak memiliki dua kondisi ${ }^{12}$ :

1. Harta itu mengikuti harta yang tidak bergerak (al-'Iqar). Jika harta itu dikaitkan dengan harta tidak bergerak sesuai dengan kesepakatan, maka wakafnya sah, sebab termasuk juga dalam wakaf harta tidak bergerak, walaupun tidak disebutkan.

Ibnu Hammam menyatakan bahwa dalam mewakafkan tanah, bangunan yang terdapat di atas tanah itu termasuk benda

${ }^{12}$ Al-Syaikh Musthafa Ahmad al-Zarqa. (1419 H/ 1998 M). Ahkam al-Awqaf. hlm. 367. yang diwakafkan juga. Sedangkan jika yang termasuk dalam wakaf tanah itu pepohonan, maka terbagi menjadi dua pendapat:

a) Fatwa Qadhi Khan, pepohonan dan bangunan yang ada di atas tanah wakaf termasuk harta yang diwakafkan. Demikian juga jika tanah tersebut dijual, maka bangunan dan pohonpohon di atasnya termasuk dalam tanah yang telah dijual.

b) Adapun buah-buahan yang ada di pohon tidak termasuk sesuatu yang diwakafkan ketika tanah itu diwakafkan. Kecuali jika dikatakan sebagai tambahan dalam akad wakaf: “Aku wakafkan tanah ini beserta apa yang ada di dalamnya dan di atas tanah ini."

2. Harta itu tidak mengikuti harta tidak bergerak yang diwakafkan (harta bergerak yang mandiri). Dalam hal ini, al-Kabisi menyatakan bahwa wakaf tersebut tidak sah, kecuali 
mengikuti beberapa hal berikut ini:

a) Ada nash syar'i, baik dari al-Quran atau hadits yang menjelaskan bentuk harta yang diwakafkan, seperti: wakaf persenjataan atau hewan ternak, seperti kuda dan keledai. Ulama Hanafiyah memberlakukan wakaf benda bergerak atas dasar penalaran istihsan. Adapun Nash syar'i yang menjadi landasan istihsan ulama Hanafiyah adalah hadits berikut ini:

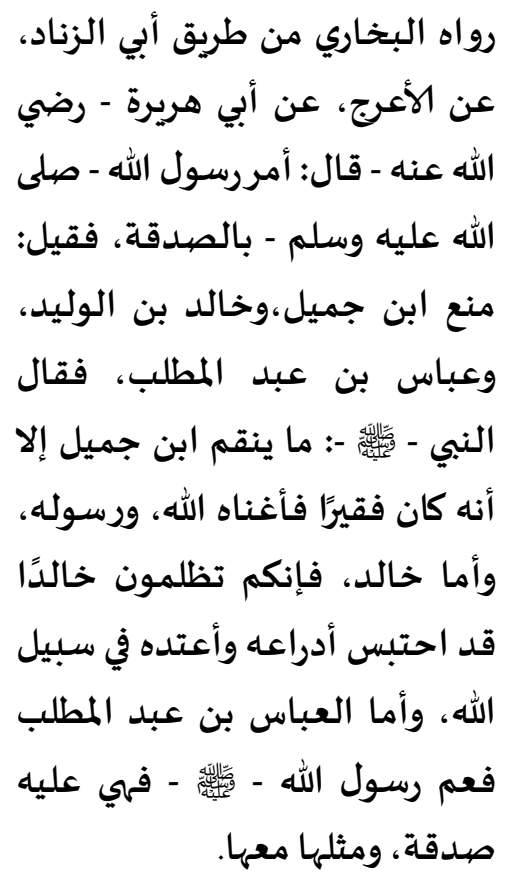

Hadits tersebut menjadi wakaf benda-benda bergerak. Selanjutnya, seperti yang diriwayatkan olehh Thalhah yang mewakafkan perisainya dan dalam riwayat lain, ia mewakafkan keledainya. Thabrani meriwayatkan dari Ibnu Mubarak dengan sanad Abu Wa'il, dia berkata:" ketika Khalid bin Walid wafat, ia berkata: Aku telah minta diikutsertakan dalam peperangan. Namun aku tidak diberikan kekuatan hingga aku pun wafat di atas ranjangku. Tidak ada satu pekerjaan pun yang paling baik, kecuali menegakkan kalimah La Ilaha Illa Allah. Kemudian ia berkata: Jika aku meninggal dunia lihatlah pada senjataku dan tungganganku, kemudian jadikan semuanya sedekah di jalan Allah.

b) Sudah menjadi tradisi (adat) dalam wakaf, seperti: wakaf al-Quran, buku-buku agama dan fasilitas masjid.

dalil atas dibolehkannya 
Dalam hal wakaf berdasarkan tradisi masyarakat setempat, menurut pendapat Muhammad ${ }^{13}$, bahwa maksud dari tradisi dalam masalah wakaf adalah apa yang secara umum ada dalam setiap waktu dan tempat, berbaur dengan tradisi baru dan tidak ada ketentuannya pada masa sahabat. Sebagian ulama mazhab Hanafi, menambahkan bahwa tradisi yang dimaksud adalah suatu hal yang baru sebagai produk dari pola interaksi (al-ta'âmul) masyarakat. Dengan demikian, sesuatu yang bukan merupakan hasil dari interaksi antar masyarakat, tidak bisa diwakafkan. Setiap benda yang digunakan oleh suatu lapisan masyarakat pada suatu masa dan tempat tertentu, tidak bisa diwakafkan lagi pada masa dan tempat lainnya jika masyarakat tersebut sudah tidak menggunakannya lagi.

Seluruh ulama fikih telah
sepakat bahwa harta yang bisa
diwakafkan meliputi harta tidak
bergerak yang berupa tanah, sawah dan
ladang, dan harta bergerak. Namun,
beberapa ulama mazhab berbeda
pendapat dalam menetapkannya.

${ }^{13}$ Muhammad Abid Abdullah al-Kabisi. (1397 H/1977 M). Ahkam al-Waqf fi alSyari'ah al-Islamiyyah. Mathba'ah al-Irsyad, Baghdad, hlm. 372.
Berikut beberapa pandangan para ulama tersebut ${ }^{14}$ :

\section{Mazhab Maliki}

Menurut mazhab ini, mewakafkan harta bergerak adalah boleh. Alasan kebolehannya wakaf harta bergerak adalah karena sifat kekal tidak harus ada dalam syarat sahnya wakaf. Mereka menyatakan bahwa wakaf itu sah dalam waktu tertentu yang kemudian, benda wakaf tersebut bisa menjadi milik wakif lagi. Dengan demikian, sahnya wakaf dalam waktu tertentu berimplikasi pada harta yang diwakafkan tidak harus kekal, abadi dan tidak dapat berubah. Oleh karena itu mewakafkan mata uang, dalam perspektif mazhab ini adalah boleh.

Jika benda bergerak diwakafkan untuk selamanya, maka cara untuk mengekalkannya adalah dengan penggantian (al-Istibdâl). Dengan demikian, status harta bergerak ini digantikan oleh harta yang tidak bergerak. Disyaratkan

\footnotetext{
${ }^{14}$ Muhammad Abid Abdullah al-
} Kabisi. (1397 H/ 1977 M). Ahkam alWaqf fi al-Syari'ah al-Islamiyyah. hlm. 378. 
dalam mewakafkan benda bergerak itu adalah harta yang bisa dipinjamkan, ketika barang tersebut dikembalikan penggantinya, harta wakaf itu tidak menghilangkan identitasnya. Dari sisi inilah, asas manfaat dalam wakaf menjadi paradigma wakaf benda bergerak dalam mazhab Maliki.

2. Mazhab Syafi' $i$

Mazhab Syafii membolehkan wakaf benda bergerak seperti halnya wakaf benda tidak bergerak karena yang menjadi dasar dalam wakaf adalah keabadiannya. Hukum sahnya wakaf benda bergerak didasari dari dua landasan:

1) Kekekalan adalah standar utama dalam setiap bentuk wakaf. Arti kekal dalam wakaf, menurut mazhab ini adalah harta tersebut selama benda itu masih ada dan dimanfaatkan. Kekekalan segala sesuatu adalah sampai batas keberadaannya dapat dimanfaatkan.

2) Wakaf tidak berakhir dengan musnahnya harta bergerak, tetapi harus digantikan dengan harta lain dan penggantinya itu akan menempati posisi harta bergerak yang sudah musnah (prinsip istibdal).

3. Pendapat Mazhab Hambali

Mazhab ini telah menyelaraskan antara syarat kekekalan dan bolehnya wakaf harta bergerak dengan syarat ada pengganti (prinsip istibdâl). Sehingga harta wakaf itu berstatus kekal dan abadi. Nampaknya, pendapat mazhab Hambali selaras pula dengan mazhab Syafii dalam bolehnya wakaf benda bergerak.

\section{Wakaf Benda Bergerak Dalam Bentuk Mata Uang}

Perbincangan tentang wakaf tunai mulai mengemuka dalam beberapa tahun belakangan ini. Hal ini terjadi seiring berkembangnya sistem perekonomian dan pembangunan yang memunculkan inovasi-inovasi baru. Wakaf tunai sebagai instrumen finansial (financial instrument), keuangan sosial dan perbankan sosial (social finance and voluntary sector banking) dipelopori oleh Prof. M.A. 
Mannan (2002), pakar ekonomi asal Bangladesh. Wakaf tunai yang digagas oleh Mannan merupakan produk baru dalam sejarah perekonomian Islam. Instrumen finansial yang dikenal dalam perekonomian Islam selama ini berkisar pada murabahah untuk membiayai sektor perdagangan dan mudarabah atau musyarakah untuk membiayai investasi di bidang industri dan pertanian. Bank juga tidak mau menerima tanah atau aset lain yang merupakan harta wakaf untuk dijadikan jaminan. Karena harta wakaf bukan hak milik, melainkan hak pakai terhadap manfaat harta wakaf itu.

'Uang' adalah sesuatu yang secara umum diterima guna pembayaran barang dan jasa; dan berfungsi sebagai kekayaan bagi pemiliknya ${ }^{15}$. Dalam bahasa Arab, uang atau cash atau tunai adalah al-naqd atau al-nuqûd (plural). Definisi tentang uang dalam bahasa Arab beragam, diantaranya: al-Jayyid al-Wâzin min al-darâhim (yang baik dari dirham), qabdh al-darâhim (meraih dirham), tamyîz al-darâhim wa ikhrâj

${ }^{15}$ Uswatun Hasanah, et.al. (2011). Aspek Hukum Wakaf Uang. Jakarta: Badan Pembinaan Hukum Nasional, Kementerian Hukum dan Hak Asasi Manusia RI, hlm. 77. al-zayf (membedakan dirham dan mengeluarkan yang palsu) ${ }^{16}$, Khilâf alnasi'ah (antonim dari kredit) atau $m a$ yu'thâ min al-tsamân mu'ajjal aldirhâm (memberikan bayaran dirham dengan segara/muajjal) ${ }^{17}$.

Kata Nuqûd tidak ditemukan di dalam al-Quran maupun hadits Nabi karena bangsa Arab pada umumnya tidak menggunakan kata nuqûd untuk menunjukkan harga (al-atsmân). Bangsa Arab menggunakan dinar mata uang yang diambil dari tradisi Romawi, Denarius, yaitu nama untuk emas cetakan untuk menunjukkan mata uang yang terbuat dari emas, dan dirham mata uang yang diambil dari tradisi Yunani, Drachma, yaitu nama untuk perak yang dicetak untuk menunjukkan mata uang dari perak. Mereka juga menggunakan kata wariq untuk menunjukkan dirham perak, dan kata 'ayn untuk menunjukkan dinar emas. Kata fulûs, plural dari fals, (uang tembaga) adalah alat tukar tambahan

${ }^{16}$ Ahmad Hasan. (1420 H/1999 M). alAwraq al-Naqdiyyah Fi al-Iqtishad al-Islamiy qimatuha wa hukmuha. Beyrut: Dar al-Fikr, Damaskus, hlm. 29.

${ }^{17}$ Abi Suud Muhammad ib Muhammad ibn Mushtafa al-Imadi al-Afandy al-Hanaf. (1417 H/1997 M). Risalah fi Jawaz Waqf alNuqud. Dar Ibn Hazm, hlm. 7. 
yang digunakan untuk membeli barangbarang yang murah ${ }^{18}$.

Selanjutnya, apabila kita perhatikan para pendapat ulama fiqih tentang pengertian dari dua mata uang (naqdân), emas dan perak adalah sebagai berikut:

Berkata Imam al-Syarbini: kalau dimutlakkan, maka berkata: aku tukar satu dinar dengan dua puluh dirham dan di sana hanya ada satu mata uang saja (naqd) yang tidak berbeda-beda atau beberapa mata uang yang berbeda-beda kecuali bahwa sesungguhnya salah satunya lebih ghalib maka sah dan hilanglah kemutlakan atas mata uang tersebut. Ibnu Qudamah, seorang faqih mazhab Hanbali menyatakan bahwa 'dan dalam hal pendapat yang menyatakan bahwa berinfak dengan mata uang (nuqud) yang tidak lagi murni maka yang lebih logis adalah diperbolehkan berinfak dengan naqd yang tidak murni. Ibnu Qudamah menegaskan lagi bahwa zakat harta adalah dengan emas dan perak. ${ }^{19}$

${ }^{18}$ Ahmad Hasan. (1420 H/ 1999 M). alAwraq al-Naqdiyyah Fi al-Iqtishad al-Islamiy qimatuha wa hukmuha. hlm. 30.

${ }^{19}$ Ahmad Hasan. (1420 H/ 1999 M). alAwraq al-Naqdiyyah Fi al-Iqtishad al-Islamiy qimatuha wa hukmuha. hlm. 31.
Sementara mata uang (emas dan perak/naqd) tidak dikhususkan bagi mata uang emas dan perak yang dicetak/dicampur saja, namun mencakup keduanya. Al-Syarwani, diantaranya menyatakan mata uang emas dan perak walaupun tidak dicampur atau dicetak (emas dan perak murni), dan takhsis terhadap apa yang dicetak atau tidak dicampur, tertolak dalam urf perspektif fuqaha.

Definisi uang menurut para ahli ekonomi, sebagaimana yang dikutip Ahmad Hasan dari J.P. Crowther adalah segala sesuatu yang diterima secara luas sebagai alat pembayaran utang-utang dan pembayaran harga barang dan jasa $^{20}$. Nazhim al-Syamsy menyatakan bahwa setiap sesuatu yang diterima semua pihak dengan legalitas tradisi (urf) atau undang-undang, atau nilai sesuatu itu sendiri, dan mampu berfungsi sebagai media dalam proses transaksi pertukaran yang beragam terhadap komoditi dan jasa, juga cocok untuk menyelesaikan utang-piutang dan tanggungan, adalah termasuk dalam lingkup uang.

\footnotetext{
${ }^{20}$ Ahmad Hasan. (1420 H/ 1999 M). alAwraq al-Naqdiyyah Fi al-Iqtishad al-Islamiy qimatuha wa hukmuha. hlm. 37.
} 
Ahmad Hasan menyimpulkan bahwa uang bisa dibedakan dari tiga $\operatorname{segi}^{21}$ :

1. Definisi uang dari segi fungsi-fungsi ekonomi sebagai standar ukuran nilai, media pertukaran, dan alat pembayaran yang tertunda (deffered payment).

2. Definisi uang dengan melihat karakteristiknya; segala sesuatu yang diterima secara luas oleh setiap individu.

3. Definisi uang dari segi peraturan perundangundangan sebagai segala sesuatu yang memiliki kekuatan hukum dalam menyelesaikan segala tanggungan (ibra' aldzimmah)

Sesuatu yang dianggap 'uang' memiliki enam kriteria: Penerimaan dan dapat diketahui (acceptability and cognizability), Stabilitas nilai (stability of value), Keseimbangan (elasticity of supply), Kemudahan (portability),

${ }^{21}$ Ahmad Hasan. (1420 H/1999 M). alAwraq al-Naqdiyyah Fi al-Iqtishad al-Islamiy qimatuha wa hukmuha. hlm. 38.
Terjaga fisiknya (durability), dan Pemantapan transaksi (divisibility). Selanjutnya, menurut Uswatun Hasanah, jenis uang dibedakan dari dua segi; a) dari segi bahan pembuatan; dan b) dari segi nilai. Dari segi bahan material, uang dibedakan menjadi dua: a) uang logam, dan b) uang kertas. Sedangkan dari segi nilai, uang dibedakan menjadi dua: a) uang yang bernilai penuh (full bodied money), dan b) uang yang tidak bernilai penuh (representative full bodied money) atau 'uang bertanda'. Uang yang bernilai penuh (full bodied money) adalah uang yang nilai yang dikandungnya sama dengan nilai nominalnya (intrinsik). Uang yang bernilai penuh hanya ada pada uang logam: emas, perak, perunggu. Sedangkan uang yang tidak bernilai penuh (representative full bodied money) adalah uang yang nilai intrinsiknya lebih kecil dari pada nilai nominalnya. Uang yang tidak bernilai penuh tidak mempunyai nilai yang berarti sebagai barang nonmoneter, tetapi uang ini dalam peredaran 'mewakili' sejumlah logam tertentu dengan nilai yag sama besarnya dengan nilai nominal uangnya. Adapun uang kertas yang beredar saat ini tidak 
mewakili sejumlah (seberat) logam tertentu yang disimpan di bank sentral. Dengan demikian, uang yang tidak bernilai penuh tidak dapat ditukarkan dengan seberat logam tertentu di bank ${ }^{22}$.

Secara bahasa wakaf uang adalah wakaf dalam bentuk uang atau cash waqf atau wakaf tunai. Wakaf uang dalam pengertian Badan Wakaf Indonesia adalah wakaf berupa uang yang dapat dikelola secara produktif. Hasilnya dimanfaatkan untuk mawquf alaih $^{23}$. Sementara, pengertian wakaf uang yang disusun dalam Fatwa MUI yang ditandatangani oleh KH. Ma'ruf Amien dan Drs. H. Hasanudin, M.Ag di Jakarta pada tanggal 28 Shafar 1423 H/11 Mei 2002 M dinyatakan bahwa (1), wakaf uang (cash waqf/waqf alNuqud) adalah wakaf yang dilakukan seseorang, kelompok orang, lembaga atau badan hukum dalam bentuk uang tunai. (2), Termasuk dalam pengertian wakaf uang adalah surat-surat berharga.

Pendapat para ulama yang membolehkan wakaf uang sebagaimana yang termaktub dalam kitab Risalah fi

\footnotetext{
${ }^{22}$ Uswatun Hasanah, et.al. (2011). Aspek Hukum Wakaf Uang. hlm. 78.

${ }^{23}$ Forum Lembaga Keuangan Syariah Penerima Wakaf Uang. (2011). Handbook Wakaf Uang. hlm. 2.
}

jawaz waqf al-nuqud sebagai berikut ini $^{24}$ :

1. Bahwa diperbolehkannya wakaf uang berakar dari pendapat Zafar ${ }^{25}$ yang terdapat dalam kita-kitab fiqih Hanafiyah.

2. Selanjutnya, pendapat tersebut dinisbahkan pada keabsahan wakaf uang dinar kepada Ibn Syihab al-Zuhri sebagaimana yang dikutip dalam kitab Shahih Bukhari. Dalam kitab tersebut dinyatakan: bahwa al-Zuhri berpendapat: 'bagi siapa saja yang hendak menjadikan seribu dinar di jalan Allah, dan diberikan kepada seorang anak yang mempunyai seorang pengusaha, lalu (uang seribu dinnar itu) dikembangkan hingga menghasilkan laba besar, labanya itu disedekahkan kepada fakir miskin dan

${ }^{24}$ Abi Suud Muhammad ib Muhammad ibn Mushtafa al-Imadi al-Afandy al-Hanafi. (1417 H/1997 M). Risalah fi Jawaz Waqf alNuqud. hlm. 20.

${ }^{25}$ Nama aslinya adalah Zafar Ibn Huzail Abu al-Hudzayl al-'Anbary. (158 H). sahabat sekaligus murid dari Imam Abu Hanifah. Lihat, Abu Su'ud, ibid. 
kaum kerabat. Apakah bagi

orang tersebut bisa

mengkonsumsi dari sebagian

keuntungannya dari ribuan

dinar itu, dan kalau tidak

maka sedekahkan kepada

fakir miskin. Al-Zuhri

berkata: bagi orang tersebut

tidak (untuk mengkonsumsi

sebagian keuntungannya).

قال الزهري فيمن جعل

ألف دينار في سبيل الله

ودفعها إلى غلام لله تاجر

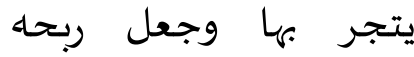

صدقة للمساكين والأقربين

هل للرجل أن يأكل من ربح

ذلك الألف شيئا وإن لم لم

يكن جعل ربحها صدقة في

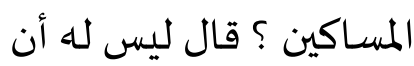

يأكل منها

Berkata Imam al-Zuhri

dalam hal seseorang

yang menjadikan seribu

dinar di jalan Allah dan

memberikannya kepada

seorang pedagang yang

memiliki budak yang

akan memperdagangkan

dengan uang tersebut.

Lalu, keuntungannya dijadikan sebagai

sedekah bagi orang

miskin dan kaum

kerabat. Apakah bagi

orang tersebut

diperbolehkan untuk

mendapatkan bagian

dari keuntungan seribu

dinar itu barang sedikit?

Kalau pun seandainya

tidak, menjadikan

keuntungannya itu

sebagai sedekah bagi

fakir miskin. Menjawab

al-Zuhri: tidak ada

baginya untuk

mendapatkan bagian

dari keuntungannya itu.

Di dalam 'al-Mabsuth', sebagaimana yang dikutip Abu Suud, Imam al-Sarakhsiy menyatakan bahwa ada perbedaan pandangan antara $\mathrm{Abu}$ Yusuf dan Muhammad tentang wakaf harta yang bergerak (al-manqul). Adapun jawaban dari perbedaan pandangan itu adalah 'bahwa apa yang sudah berlaku sebagai tradisi di antara manusia termasuk wakaf tunai di 
dalamnya, maka diperbolehkan dengan pertimbangan ' $u r f$ ',26.

Al-Shadr al-Syahid dalam 'almuhith' menyatakan bahwa Muhammad (Muhammad Ibn Hasan al-Syaybani) berkata: apa yang sudah menjadi adat dan kebiasaan (urf) manusia dalam hal wakaf harta yang bergerak (al-manqul), maka bahwa sesungguhnya wakaf jenis itu diperbolehkan berdasarkan penalaran istihsan; seperti wakaf gergaji, kapak, periuk, keranda mayat, buku dan lain sebagainya. Namun, apabila wakaf tidak berdasarkan adat/kebiasaan manusia, maka wakaf tersebut tidak diperbolehkan seperti wakaf tempat air dari kulit atau binatang ${ }^{27}$.

Melihat dari beragam pendapat tersebut, maka bisa ditarik kesimpulan: sekiranya menjadikan pengalihan wakaf, nilai dan harganya dan apa yang bisa dibeli dengan nilai dan harga itu tetap dan kekal, lalu apabila harta tersebut dimanfaatkan namun

${ }^{26}$ Abi Suud Muhammad ib Muhammad ibn Mushtafa al-Imadi al-Afandy al-Hanafi. (1417 H/1997). Risalah fi Jawaz Waqf alNuqud. hlm. 25.

27 Burhanuddin Mazah Mahmud bin Ahmad bin al-Shadr al-Syahid al-Najjariy. alMuhith al-Burhaniy. Beyrut: Dar Ihya al-Turats al-'Arabbiy, Juz V, tt, hlm. 705. pokok/asalnya tetap, maka wakaf tunai itu lebih utama.

\section{Ketentuan Hukum Wakaf Benda Bergerak Dalam Perspektif Perundang- Undangan}

Dalam Undang-Undang Nomor 41 tahun 2004 tentang Wakaf Bagian Keenam Harta Benda Wakaf, Pasal 16 dinyatakan bahwa:

(1) Harta benda wakaf terdiri dari:

a. benda tidak bergerak; dan

b. benda bergerak.

(2) Benda tidak bergerak sebagaimana dimaksud pada ayat (1) huruf a meliputi:

a. hak atas tanah sesuai dengan ketentuan peraturan perundangundangan yang berlaku baik yang sudah maupun yang belum terdaftar;

b. bangunan atau bagian bangunan yang berdiri di atas tanah sebagaimana dimaksud pada huruf a; 
c. tanaman dan benda lain yang berkaitan dengan tanah;

d. hak milik atas satuan rumah susun sesuai dengan ketentuan peraturan

perundangundangan yang berlaku;

e. benda tidak bergerak lain sesuai dengan ketentuan syariah dan peraturan perundangundangan yang berlaku.

(3) Benda bergerak sebagaimana dimaksud pada ayat (1) huruf $b$ adalah harta benda yang tidak bisa habis karena dikonsumsi, meliputi:
a. uang;
b. logam mulia;
c. surat berharga;
d. kendaraan;
e. hak atas kekayaan intelektual;
f. hak sewa; dan
g. benda bergerak lain sesuai dengan ketentuan syariah dan peraturan perundang undangan yang berlaku.

Di dalam Undang-Undang Republik Indonesia no. 41 Tahun 2004 Tentang Wakaf, Bagian Kesepuluh, Wakaf Benda Bergerak Berupa Uang, Pasal 28 dinyatakan bahwa Wakif dapat mewakafkan benda bergerak berupa uang melalui lembaga keuangan syariah yang ditunjuk oleh Menteri. Pasal 29 menyatakan bahwa: (1) Wakaf benda bergerak berupa uang sebagaimana dimaksud dalam Pasal 28 dilaksanakan oleh Wakif dengan pernyataan kehendak Wakif yang dilakukan secara tertulis. (2) Wakaf benda bergerak berupa uang sebagaimana dimaksud pada ayat (1) diterbitkan dalam bentuk sertifikat wakaf uang. (3) Sertifikat wakaf uang sebagaimana dimaksud pada ayat (2) diterbitkan dan disampaikan oleh lembaga keuangan syariah kepada Wakif dan Nazhir sebagai bukti penyerahan harta benda wakaf.

Selanjutnya, dalam Peraturan Pemerintah Republik Indonesia Nomor 42 tahun 2006 tentang Pelaksanaan Undang-Undang No. 41 Tahun 2004, dinyatakan dalam Paragraf 3 Benda Bergerak Berupa Uang, Pasal 22 dinyatakan bahwa: (1) Wakaf uang yang dapat diwakafkan adalah mata 
uang rupiah. (2) Dalam hal uang yang akan diwakafkan masih dalam mata uang asing, maka harus dikonversi terlebih dahulu ke dalam rupiah.(3) Wakif yang akan mewakafkan uangnya diwajibkan untuk: hadir di Lembaga Keuangan Syariah Penerima Wakaf Uang (LKS-PWU) untuk menyatakan kehendak wakaf uangnya; menjelaskan kepemilikan dan asal-usul uang yang akan diwakafkan; menyetorkan secara tunai sejumlah uang ke LKSPWU; mengisi formulir pernyataan kehendak Wakif yang berfungsi sebagai AIW. (4) Dalam hal Wakif tidak dapat hadir sebagaimana dimaksud pada ayat (3) huruf a, maka Wakif dapat menunjuk wakil atau kuasanya. (5) Wakif dapat menyatakan ikrar wakaf benda bergerak berupa uang kepada Nazhir di hadapan PPAIW yang selanjutnya Nazhir menyerahkan AIW tersebut kepada LKS-PWU. Pasal 23 menyatakan bahwa Wakif dapat mewakafkan benda bergerak berupa uang melalui LKS yang ditunjuk oleh Menteri sebagai LKS Penerima Wakaf Uang (LKS-PWU).

\section{E. PENUTUP}

Wakaf adalah salah satu instrumen ekonomi Islam yang unik. Dengan karakter khasnya sebagai pengalihan kepemilikan harta individu (private property) ke kepemilikan harta bagi Allah (divine property), meniscayakan harta wakaf menjadi milik publik yang abadi dan harus tetap utuh dan terjaga sumbernya. Menilik karakter khas wakaf yang seperti itu, memungkinkan institusi wakaf menjadi aset ekonomi produktif yang harus terus menerus berkembang untuk digunakan seluas-luasnya dalam menyejahterakan umat. Berbeda dengan harta ZIS yang terikat dengan batas minimum (nishab) dan kadar zakat yang akan habis didistribusikan dan dikonsumsi, harta wakaf akan terus berkembang, saat mana asal/pokok hartanya dijadikan sumber daya ekonomi yang tetap dan produktif. Harta wakaf tidak terikat dengan adanya batas minimum dan kadar.

Wakaf benda bergerak yang sudah dirintis sejak awal dalam tradisi rasul yang kemudian mendapatkan legitimasi ijma' para ulama, sejatinya dipraktekkan secara luas dalam wakaf di Indonesia dan berimplikasi positif 
terhadap pertumbuhan ekonomi. Dalam mewujudkan animo masyarakat terhadap wakaf benda bergerak, perlu adanya reinterpretasi terhadap fikih wakaf benda bergerak dan perundangundangan di Indonesia.

\section{DAFTAR PUSTAKA}

al-Anshari, M. I.-I. (n.d.). Lisan alArab. Beirut: Dar al-Shadr.

al-Dubyan, A. '. $(1432 \mathrm{H}) . \quad$ alMu'amalat al-Maliyah Ashalah wa Mu'asharah . Riyadh: Maktabah al-Malik Fahd alWathaniyyah .

al-Hanafi, A. S.-I.-A. (1417 H/1997 M). Risalah fi Jawaz Waqf alNuqud. Dar Ibn Hazm.

al-Kabisi, M. A. (1397 H/1977 M). Ahkam al-Waqf fi Syari'ah alIslamiyah. Baghdad: Mathba'ah al-Irsyad.

al-Najjariy, B. M.-S.-S. (n.d.). alMuhith al-Burhaniy. Beyrut: Dar Ihya al-Turats al-'Arabbiy.

al-Zarqa, A.-S. M. (1419 H/1998 M). Ahkam al-Awqaf. Amman, Yordania: Dar Ammar.
Chapra, M. U. (1992/1413 H). Islam and the Economic Challenge, The Islamic Foundation And The International Institute of Islamic Thought. Saudi Arabia: Riyadh 11532 .

Direktorat Pemberdayaan Wakaf, K. A. (2013.). Strategi Pengembangan Wakaf Tunai di Indonesia.

Forum Lembaga Keuangan Syariah Penerima Wakaf Uang, ,. (2011 ). Handbook Wakaf Uang.

Hasan, A. (1420 H/1999 M). al-Awraq al-Naqdiyyah Fi al-Iqtishad alIslamiy qimatuha wa hukmuha . Damaskus, Beyrut: Dar al-Fikr.

Lubis, S. K. (2004). Hukum Ekonomi Islam. Jakarta: Sinar Grafika.

Uswatun Hasanah, e. (2011). Aspek Hukum Wakaf Uang. Jakarta: Badan Pembinaan Hukumm Nasional, Kementerian Hukum dan Hak Asasi Manusia RI.

Jurnal al-Iqtishad, Vol. VI, No. 2, Juli 2014

Jurnal Ahkam: Vol. XII, No. 2, Juli 2012

Jurnal La Riba, Vol. IV, No.1, Juli 2010 